\title{
Gangguan Ginjal terkait Obesitas pada Anak
}

Sudung O. Pardede, ${ }^{*}$ Alvina Christine, ${ }^{*}$ Jumaini Andriana**

${ }^{*}$ Departemen Ilmu Kesehatan Anak Fakultas Kedokteran Universitas Indonesia/RS Dr. Cipto Mangunkusumo, **Fakultas Kedokteran Universitas Kristen Indonesia, Jakarta

\begin{abstract}
Abstrak
Prevalensi obesitas pada anak serta komplikasinya cenderung mengalami peningkatan. Salah satu komplikasi obesitas adalah kelainan ginjal yang disebut obesity-related renal injury atau gangguan ginjal terkait obesitas. Banyak faktor yang berperan dalam terjadinya obesity-related renal injury. Overweight atau obesitas berhubungan erat dengan berbagai faktor risiko penyakit ginjal kronik yaitu hiperinsulinemia, gangguan metabolisme glukosa, hipertensi, hiperlipidemia, dan sindrom metabolik. Di antara semua faktor tersebut, faktor yang paling berperan antara obesitas dan kerusakan ginjal adalah berkurangnya sensitivitas insulin. Manifestasi klinis obesityrelated renal injury pada umumnya berupa proteinuria bermakna tanpa edema, albumin plasma sedikit menurun, dan kolesterol normal atau sedikit meningkat. Salah satu tata laksana obesity-related renal injury adalah penurunan berat badan. Pengurangan asupan diet dan penurunan berat badan dapat menyebabkan berkurangnya lesi glomerulosklerosis fokal segmental. Terapi lainnya adalah pemberian obat yang memiliki efek negatif terhadap sistem renin-angiotensin seperti inhibitor angiotensin-converting-enzyme dan angitensin receptor blocker. Dapat juga diberikan obat yang meningkatkan sensitivitas insulin. Golongan statin mempunyai peran dalam melindungi ginjal. Usaha mencegah atau menangani obesitas sejak dini memberikan dampak besar terhadap insidens, progresivitas, biaya, dan komorbiditas penyakit ginjal. Sari Pediatri 2017;18(6):504-12
\end{abstract}

Kata kunci: obesitas, renal injury, glomerulosklerosis fokal segmental, anak

\section{Obesity-related Renal Injury in Children}

\author{
Sudung O. Pardede, ${ }^{*}$ Alvina Christine, ${ }^{*}$ Jumaini Andriana**
}

\begin{abstract}
The prevalence of obesity and its complication in children tends to increase. One of obesity complications is renal abnormality called obesity-related renal injury. There are several factors that contribute to obesity-related renal injury. Overweight or obesity has a strong correlation with many risk factors of chronic kidney disease such as hyperinsulinemia, glucose metabolism disorder, hypertension, hyperlipidemia, and metabolic syndrome. Among those risk factors, decrease insulin sensitivity plays the most crucial role between obesity and renal injury. The clinical manifestations of obesity-related renal injury are usually significant proteinuria without edema, slight decrease of plasma albumin, and normal or slightly elevated cholesterol level. One of obesity-related renal injury management is reduction of body weight. Reduction of dietary intake and body weight can reduce focal segmental glomerulosclerosis lesion. Other management include drugs that have negative effect on renin-angiotensin system such as angiotensin-converting enzyme inhibitor and angiotensin receptor blocker; and drugs that can increase insulin sensitivity. Statins also have some roles in renal protection. Early efforts to prevent or manage obesity give great impact to incidence, progressivity, cost and renal disease comorbidity. Sari Pediatri 2017;18(6):504-12
\end{abstract}

Keywords: obesity, renal injury, focal segmental glomerulosclerosis, children

Alamat korespondensi: DR. Dr. Sudung O. Pardede, SpA(K). Departemen Ilmu Kesehatan Anak Fakultas Kedokteran Universitas Indonesia/RS Dr. Cipto Mangunkusumo, Jakarta. Email: suopard@yahoo.com 
$\mathrm{O}$ besitas adalah keadaan kelebihan berat badan yang terjadi akibat penimbunan jaringan lemak tubuh secara berlebihan. Prevalensi dan beratnya derajat obesitas cenderung meningkat pada anak sehingga prevalensi komplikasi obesitas pun turut meningkat. ${ }^{1,2}$ Akhirakhir ini obesitas pada anak menjadi epidemik di seluruh dunia dengan peningkatan angka kejadian hingga tiga kali lipat, dan kurang lebih seperlima anak dan remaja di negara industri mengalami overweight atau obesitas dan di sebagian besar negara sedang berkembang mencapai hingga $10 \%{ }^{3}$ Di Indonesia menurut laporan Riset Kesehatan Dasar (Riskesdas) tahun 2007, prevalensi nasional balita gemuk adalah $12,2 \%$ dan prevalensi nasional anak usia sekolah (usia 6-14 tahun) yang gemuk untuk laki-laki 9,5\% sedangkan perempuan 6,4\%. Menurut Riskesdas tahun 2013, obesitas pada anak sebesar 10,8\%. ${ }^{4}$ Diperkirakan, pada tahun 2020, angka kejadian anak dengan overweight dan obesitas di Eropa $>35 \%$, di Amerika $>45 \%$, dan di Asia Tenggara diperkirakan mencapai $20 \%$. Data ini mengingatkan bahwa obesitas akan menjadi ancaman nyata yang menyebabkan kejadian kelainan metabolik dan kardiovaskular semakin meningkat, bukan hanya pada orang dewasa, tetapi juga pada anak dan remaja. ${ }^{3}$

Telah diketahui bahwa obesitas merupakan penyakit multifaktorial dan faktor risiko berbagai penyakit seperti hipertensi, penyakit jantung koroner, diabetes melitus, hiperkolesterolemia, hipertrigliseridemia, hiperlipoproteinemia, obstructive sleep apnea syndrome, dan gangguan psikososial, namun hubungan obesitas dengan peyakit ginjal belum banyak dilaporkan. ${ }^{1}$ Ginjal merupakan organ yang dapat langsung dipengaruhi oleh obesitas, hipertensi, maupun diabetes, ${ }^{2,3}$ namun disfungsi ginjal pada obesitas dapat terjadi sebelum terdapat hipertensi maupun diabetes. Kelainan ginjal sebagai komplikasi obesitas disebut gangguan ginjal terkait obesitas atau obesity-related renal injury. $3 ., 5,6$

Berbagai penelitian epidemiologi menunjukkan bahwa obesitas meningkatkan risiko penyakit ginjal, namun sebagian besar penelitian tentang hubungan antara obesitas dan penyakit ginjal dilakukan pada populasi dewasa. Meski penelitian serupa pada anak masih terbatas, akan tetapi hasilnya menunjukkan bahwa obesitas pada anak juga meningkatkan risiko penyakit ginjal. ${ }^{3}$ Dengan meningkatnya kejadian obesitas, maka kemungkinan akan terjadi peningkatan penyakit ginjal. Hal ini perlu diwaspadai karena penyakit ginjal dapat berlanjut menjadi penyakit ginjal stadium akhir (PGSA) yang memerlukan tindakan dialisis dan cangkok ginjal. Kelainan kardiovaskular dan ginjal pada obesitas yang sering terjadi pada orang dewasa kemungkinan sudah terjadi sejak masa kanakkanak. $^{3,5-7}$

\section{Definisi}

Gangguan ginjal terkait obesitas merupakan glomerulonefropati yang berhubungan dengan obesitas dan disebut juga dengan obesity-related glomerulopathy. Secara klinis, gangguan ginjal terkait obesitas didefinisikan dengan kelainan yang ditandai proteinuria sedang, albumin serum yang rendah, kolesterol serum yang tinggi, dan edema. ${ }^{3,8-10}$

Secara morfologi, gangguan ginjal terkait obesitas didefinisikan sebagai glomerulomegali dengan atau tanpa glomerulosklerosis fokal segmental (GSFS) yang disebabkan kelainan fungsi dan struktur ginjal. Kelainan ini terjadi sebagai akibat respons maladaptif glomerulus terhadap peningkatan jaringan adiposa pada obesitas. ${ }^{3,8-10}$

\section{Hubungan obesitas dengan kelainan ginjal}

Hubungan antara obesitas dan proteinuria pertama kali dilaporkan oleh Weisinger $\mathrm{dkk}^{11}$ pada tahun 1974. Setahun kemudian, Cohen ${ }^{12}$ (1975) menggambarkan pembesaran glomerulus, hiperselularitas ringan, dan pelebaran daerah mesangium pada pasien obesitas berat dengan fungsi ginjal normal. Gambaran ini juga ditemukan pada anak, bahkan telah dijumpai pada anak usia 3 tahun., ${ }^{313}$ Sejak saat itu, beberapa peneliti melaporkan hubungan antara obesitas dan kelainan ginjal seperti glomerulomegali dan GSFS pada obesitas. ${ }^{3}$

Selama bertahun-tahun telah diketahui bahwa obesitas berhubungan dengan GSFS, meskipun derajat hubungan dan patogenesisnya masih belum diketahui. Akhir-akhir ini insiden GSFS meningkat seiring dengan peningkatan obesitas. Terdapat bukti yang mendukung peranan resistensi insulin atau hiperinsulinemia dalam hubungan obesitas dengan penyakit ginjal. ${ }^{3,8-10}$ Penelitian epidemiologis dan observasi klinis menunjukkan bukti kuat tentang obesitas atau sindrom metabolik yang 
dicetuskan obesitas sebagai penyebab penyakit ginjal kronik (PGK). ${ }^{5}$

Kelainan ginjal akibat obesitas dapat dibedakan menjadi dua, yaitu kelainan morfologis dan fungsional. Penelitian pada hewan coba menunjukkan terjadinya perubahan morfologis pada ginjal, berupa ekspansi kapsula Bowman, proliferasi sel glomerulus, penebalan membran basalis glomerulus dan tubulus ginjal, peningkatan matriks mesangium glomerulus, dan peningkatan ukuran ginjal. Kelainan fungsional yang terjadi berupa hiperfiltrasi glomerulus, peningkatan aliran darah ginjal, hipertensi, peningkatan kadar renin dalam plasma, dan hiperinsulinemia. ${ }^{14}$

\section{Peran insulin terhadap ginjal}

Untuk mempermudah pemahaman hubungan obesitas dengan kelainan ginjal, perlu diketahui tentang peran insulin terhadap fungsi ginjal. Pada glomerulus, insulin menyebabkan peningkatan laju filtrasi glomerulus (LFG) yang kemungkinan disebabkan efek vasodilatasi langsung atau karena efek antinatriuretik. Pada tubulus, insulin menimbulkan efek antinatriuretik dan meningkatkan reabsorbsi natrium, aliran plasma ginjal, beban filtrasi glukosa, dan kadar aldosteron plasma. ${ }^{3}$ Selain itu, insulin dapat memengaruhi sistem renin-angiotensin-aldosteron, meningkatkan aktivitas retensi natrium dan penambahan volume. Insulin juga meningkatkan efek angiotensin-II pada sel mesangium sehingga berkontribusi dalam terjadinya hipertensi, meningkatkan tekanan intraglomerulus, eksaserbasi proteinuria, menginduksi pengeluaran sitokin inflamatori ginjal dan growth factor, serta apoptosis. Insulin sendiri dapat menyebabkan proliferasi sel mesangium dan produksi protein matriks ekstraselular, mengubah jenis kolagen interstitium dan membran basalis yang diekskresi oleh sel mesangium. Insulin juga menstimulasi ekspresi growth factor lainnya seperti insulin-like growth factor-1 (IGF-1) dan transforming growth factor-b1 (TGF-b1) yang terlibat dalam proses mitogenik dan fibrotik seperti pada nefropati diabetik; serta meningkatkan aktivitas growth factor jaringan ikat yang mempunyai peran profibrogenik pada sel tubulus ginjal dan fibroblas interstitial. ${ }^{3}$

Adipositas tipe viseral ditandai dengan disfungsi jaringan lemak yang merupakan sumber sitokin proinflamatori termasuk komponen sistem reninangiotensin-aldosteron, tumor necrosisfactor-a (TNF- $\alpha$ ), interleukin-1 (IL-1), interleukin-6 (IL-6), C-reactive protein (CRP), leptin, dan resistin. Penurunan sensitivitas insulin dapat menyebabkan pengeluaran sitokin tersebut dari jaringan adiposa. Beberapa sitokin dapat memediasi patofisiologi penyakit ginjal dan berkontribusi terhadap ekspansi mesangium glomerulus, remodeling podosit, hilangnya integritas slit pore diaphragm, dan penebalan membran basalis.

Sensitivitas insulin sangat berkaitan erat dengan petanda stres oksidatif dan sebaliknya dengan kadar antioksidan. Derajat sensitivitas insulin berhubungan dengan produksi nitric oxide (NO), Pada populasi obesitas, terdapat penurunan NO dibandingkan dengan anak normal yang mengindikasikan peran penurunan sensitivitas insulin terhadap disfungsi endotel. Pada obesitas dengan penurunan sensitivitas insulin, hubungan overaktivitas simpatetik dan gangguan sintesis NO kelihatannya berperan terhadap hipertensi dan risiko kardiovaskular. ${ }^{3}$

\section{Patofisiologi gangguan ginjal terkait obesitas}

Salah satu fungsi ginjal adalah filtrasi yang terjadi di glomerulus. Secara histologis, glomerulus terdiri atas tiga lapisan yaitu endotel, membran basalis, dan epitel atau podosit. Pada endotel terdapat lobang yang disebut dengan fenestra, sedangkan pada sel epitel terdapat jonjot yang disebut dengan foot processus dan di antara foot processus terdapat lobang yang disebut dengan slit pore yang dilapisi dengan slit diafragma.. Membran basalis terdiri atas 3 lapisan yakni lamina rara interna, lamina densa, dan lamina rara eksterna. Proses filtrasi terjadi pada ketiga lapisan glomerulus dan ultrafiltrat akan masuk ke dalam rongga urin.

Patofisiologi gangguan ginjal terkait obesitas adalah multifaktorial. ${ }^{2}$ Kelainan pada ginjal dapat terjadi sebagai akibat langsung pada ginjal atau melalui mekanisme tidak langsung. ${ }^{2,3}$ Obesitas berkaitan dengan hiperperfusi dan hiperfiltrasi glomerulus karena maladaptasi fisiologi akibat vasodilatasi arteriol aferen. ${ }^{3}$ Penelitian eksperimental melaporkan terdapat perubahan hemodinamik ginjal akibat obesitas, berupa hiperperfusi dan hiperfiltrasi ginjal, sehingga terjadi peningkatan LFG, aliran darah ginjal, tekanan glomerulus, dan fraksi filtrasi akibat dilatasi arteriol aferen. ${ }^{15}$ Peningkatan aktivitas sistem renin-angiotensin-aldosteron akan menyebabkan aktivasi sistem 
saraf simpatetik, retensi natrium, dan ekspansi volume vaskular sehingga timbul hipertensi, hipertrofi ventrikel kiri, inhibisi sinyal insulin serta perubahan hemodinamik ginjal. ${ }^{3,14}$ Perubahan pada ginjal tersebut dapat menyebabkan inflamasi vaskular sistemik dan disfungsi endotel sehingga mengakibatkan cardiovascular-renal injury feedback loop yang progresif. ${ }^{16}$

Hiperinsulinemia yang merupakan petanda penurunan sensitivitas insulin, memegang peran penting dalam patogenesis kelainan hemodinamik ginjal. ${ }^{3}$ Penurunan sensitivitas insulin berperan meningkatkan tekanan arteriol eferen, sehingga terjadi peningkatan gradien tekanan transkapiler yang selanjutnya mengakibatkan hiperfiltrasi ginjal. ${ }^{14}$ Chagnac $\mathrm{dkk}^{17}$ melaporkan bahwa ada hubungan antara LFG dengan menurunnya sensitivitas insulin, dan diduga bahwa LFG yang meningkat pada obesitas disebabkan oleh perbedaan peningkatan tekanan hidraulik transkapiler.

Hiperinsulinemia menyebabkan peningkatan laju ekskresi albumin urin (urinary albumin excretion-rate, U-AER), akibat peran angiotensin II yang meningkatkan NADPH oksidase/ reactive oxygen species. ${ }^{16,17}$ Akibat peningkatan aktivitas angiotensin II, terjadi hipertensi, peningkatan tekanan intraglomerular, proteinuria, serta apoptosis. ${ }^{3}$ Hiperinsulinemia juga menyebabkan peningkatan sitokin proinflamasi intrarenal dan growth factor, seperti interleukin-1 (IL-1), IL-6, tumor necrosing factor- $\alpha$ (TNF- $\alpha), C$-reactive protein (CRP), leptin, dan resistin. ${ }^{3,16}$ Peningkatan sitokin dan hipertensi menyebabkan pertumtbuhan sel ginjal berupa proliferasi sel mesangium, peningkatan produksi protein matriks ekstraselular, dan stimulasi ekspresi growth factor yang kemudian menyebabkan terjadinya hipertrofi glomerulus. ${ }^{3,14}$ remodeling podosit, hilangnya integritas slit pore diaphragm, dan penebalan membran basalis, yang kemudian dapat menyebabkan glomerulosklerosis dan kerusakan tubulointerstisial. ${ }^{16}$

Pada tubulus, hiperinsulinemia dapat menyebabkan peningkatan reabsorpsi natrium dan penurunan ekskresi natrium akibat efek antinatriuretik, tanpa memengaruhi LFG. Pada glomerulus, hiperinsulinemia dapat menyebabkan peningkatan LFG yang ringan baik secara langsung atau akibat efek pada tubulus yang menyebabkan dilatasi arteriol aferen dan aktivasi sistem renin-angiotensin-aldosteron. ${ }^{3}$

Mikroalbuminuria dan proteinuria berbagai derajat juga berkorelasi positif dengan beratnya obesitas. Upaya meningkatkan sensitivitas insulin, menurunkan tekanan darah, dan pengendalian gula darah dapat mengurangi mikroalbuminuria. ${ }^{3}$ Penelitian Csernus $\mathrm{dkk}^{18}$ melaporkan peningkatan kadar albuminuria dan $\beta_{2}$-mikroglobinuria pada anak obes dan tidak terjadi pada anak dengan berat badan normal. Hal ini mengindikasikan terdapatnya disfungsi glomerulus dan tubulus ginjal dini sebagai akibat obesitas pada masa anak-anak.

Hiperinsulinemia dapat juga menyebabkan toleransi glukosa terganggu, peningkatan stres oksidatif dan penurunan produksi $\mathrm{NO}$ akibat disfungsi endotel. ${ }^{3}$ Hiperlipidemia pada obesitas terbukti menyebabkan kerusakan ginjal pada beberapa penelitian eksperimental. ${ }^{5,15}$ Penelitian oleh Jiang $\mathrm{dkk}^{19}$ melaporkan terdapatnya peningkatan ekspresi sterol regulatory element-binding proteins (SREBP-1 dan SREPB-2) oleh ginjal pada hewan coba yang mengalami obesitas. Hal ini menyebabkan akumulasi kolesterol dan trigliserida di ginjal, serta peningkatan plasminogen activator inhibitor-1 (PAI-1), vascular endothelial growth factor (VEGF), kolagen tipe IV dan fibronektin. Akumulasi faktor tersebut pada ginjal mempunyai hubungan kuat dengan terjadinya glomerulosklerosis dan proteinuria. ${ }^{15}$

Penelitian Maddox $\mathrm{dkk}^{20}$ pada tikus coba menunjukkan bahwa kadar trigliserida plasma pada tikus yang obes lebih tinggi dibandingkan dengan tikus non-obes. Pada restriksi diet, didapatkan hubungan antara penurunan trigliserida plasma dan penurunan proteinuria. Hal ini menunjukkan bahwa kadar trigliserida plasma memiliki peran penting terhadap kerusakan glomerulus pada tikus yang obes. Ditemukan juga hiperkolesterolemia sebagai akibat peningkatan kolesterol low density lipoprotein (LDL) dan very low density lipoprotein (VLDL). Pada tikus yang obes, kerusakan glomerulus akibat hiperlipidemia dapat diperantarai oleh peningkatan LDL. Sel mesangium glomerulus memiliki reseptor untuk LDL sehingga peningkatan kadar LDL meningkatkan produksi monocyte chemoattractant molecules oleh sel mesangium. Hiperkolesterolemia juga menstimulasi produksi macrophage colony-stimulating factor yang menyebabkan proliferasi dan diferensiasi monosit menjadi makrofag. Patognesis dan patofisiologi gangguan ginjal terkait obesitas tertera pada Gambar 1 (lampiran).

\section{Kaitan obesitas dengan gangguan ginjal pada anak}

Sejalan dengan peningkatan kejadian obesitas dan overweight, kejadian komplikasi obesitas seperti 
hipertensi, dislipidemia, hiperinsulinemia, obstructive sleep apnea, infiltrasi perlemakan hati, dan kelainan ortopedi juga meningkat. Obesitas-related glomerulopati, bentuk sekunder GSFS, dengan manifestasi klinis proteinuria dan disfungsi ginjal progresif, kelihatannya semakin meningkat termasuk pada anak. Obesitas-related glomerulopati disebabkan oleh maladaptasi respon glomerulus terhadap peningkatan adipositas. ${ }^{3}$

Belum banyak penelitian yang mengaitkan obesitas pada anak dengan penyakit ginjal. Obesitas pada anak meningkatkan risiko mortalitas karena penyakit ginjal. Wong $\mathrm{dkk}^{21}$ melaporkan pemantauan selama 7 tahun terhadap 3.067 anak dan menemukan terdapat hubungan bermakna antara indeks metabolik basal (basal metabolic index) dengan kematian akibat PGSA. Obesitas merupakan faktor prognostik dalam terjadinya hipertensi serta progresivitas menjadi PGK pada nefropati IgA.

Gangguan ginjal pada obesitas dapat terjadi melalui beberapa mekanisme yaitu: 1. hiperinsulinemia, 2 . gangguan metabolisme glukosa, 3. hipertensi, 4 . hiperlipidemia, 5. mikroalbuminuria, dan 6. sindrom metabolik. ${ }^{2}$ Di antara semua faktor tersebut, faktor yang paling berperan antara obesitas dan kerusakan ginjal adalah berkurangnya sensitivitas insulin. ${ }^{3}$

\section{Hiperinsulinemia atau penurunan sensitivitas insulin}

Salah satu konsekuensi penting obesitas adalah penurunan sensitivitas insulin atau hiperinsulinemia. Anak obesitas dengan body mass index (BMI) yang sama dapat mengalami derajat sensitivitas insulin yang berbeda dalam terjadinya komplikasi. Faktor risiko penyakit kardiovaskular seperti hipertensi, proteinuria, diabetes melitus tipe-2 (DMT2), dan dislipidemia, pada anak dan remaja dengan sensitivitas insulin yang lebih rendah mengindikasikan terjadinya komplikasi pada organ tertentu termasuk ginjal.

Hiperinsulinemia yang merupakan petanda penurunan sensitivitas insulin berkaitan erat dengan obesitas selama masa remaja karena penurunan fisiologis sensitivitas insulin berhubungan dengan perkembangan pubertas yang normal, namun perlu diwaspadai bahwa dapat terjadi komplikasi metabolik dan kardiovaskular pada masa prepubertal anak obes, sebagai akibat penurunan sensitivitas insulin. Hiperinsulinemia dapat memengaruhi tekanan darah dan kadar lipoprotein serum dan sering meny- ebabkan hipertensi dan dislipidemia, yang berperan dalam patogenesis glomerulopati terkait obesitas. ${ }^{3}$

\section{Gangguan metabolisme glukosa}

Diabetes melitus tipe-1 (DMT1) sering ditemukan pada anak meskipun banyak pusat pelayanan kesehatan anak melaporkan DMT2 dan overweight/ obesitas merupakan faktor risiko sangat penting dalam terjadinya DMT2. Meningkatnya prevalensi overweight sejajar dengan meningkatnya kejadian DMT2. Penurunan toleransi glukosa dan penurunan sensitivitas insulin terjadi pada DMT2. Gagal ginjal jarang karena diabetes melitus pada anak, tetapi hiperglikemia akan menyebabkan komplikasi jangka panjang. Diagnosis penyakit ginjal pada anak dengan DMT2 tidak cukup dengan gambaran klinik dan laboratorium, tetapi memerlukan biopsi ginjal. ${ }^{3}$

\section{Hipertensi}

Hubungan antara obesitas dan overweight pada anak dengan hipertensi telah dilaporkan oleh banyak peneliti. Rosner $\mathrm{dkk}^{22}$ melaporkan bahwa kejadian hipertensi 2,5-3,7 kali lebih sering pada anak obes dibandingkan anak normal. Prevalensi pre-hipertensi pun meningkat sebagai akibat obesitas. Salvadori $\mathrm{dkk}^{23}$ melaporkan bahwa pada komunitas rural di Kanada, ada hubungan yang erat antara obesitas dengan hipertensi dan prehipertensi. Hipertensi pada obesitas ini disebabkan oleh rendahnya sensitivitas insulin. Hubungan antara tekanan darah sistolik dengan kerja insulin dapat terjadi karena lifestyle atau melalui mekanisme kompleks seperti hiperfungsi simpatetik atau peningkatan inflamasi. Penurunan sensitivitas insulin yang menyebabkan hipertensi terjadi karena efek insulin yang memediasi reabsorbsi natrium di ginjal dan melalui mekanisme sistem saraf simpatetik. Selain rendahnya sensitivtas insulin, pada obesitas ditemukan juga hiperaktivitas sistem saraf simpatetik yang menyebabkan peningkatan laju jantung dan tekanan darah, peningkatan kadar katekolamin, serta peningkatan aktivitas sistem saraf simpatetik perifer. ${ }^{24-26}$ Hiperinsulinemia juga meningkatkan produksi norepinefrin plasma yang menyebabkan hipertensi. ${ }^{27}$

Pada keadaan sensitivitas insulin yang rendah, disglisemia dan dislipidemia, prekursor peningkatan tekanan darah dapat menyebabkan kerusakan 
ginjal yang menimbulkan hilangnya nefron ginjal. Hilangnya nefron secara struktural dan fungsional akan menimbulkan hipertensi juga. Penurunan LFG pada anak dengan prehipertensi akan menimbulkan proteinuria yang menandakan bahwa peningkatan tekanan darah yang ringan pun menyebabkan pasien berisiko mengalami kerusakan ginjal. ${ }^{3}$

\section{Mikroalbuminuria}

Mikroalbuminuria sering terdapat pada anak dengan obesitas. Burgert $\mathrm{dkk}^{28}$ mendapatkan sekitar $10 \%$ mikroalbuminuria pada dewasa obes dan remaja prediabetik berkaitan dengan kelainan metabolisme glukosa dan hilangnya sensitivitas insulin. Penelitian lain melaporkan bahwa derajat albuminuria dan mikroalbuminuria b-2 pada anak lebih tinggi dibandingkan dengan anak normal. $\mathrm{Hal}$ ini mengindikasikan disfungsi glomerulus dan tubulus ginjal sebagai akibat obesitas. Rasio albumin/kreatinin urin berkaitan dengan sindrom metabolik terutama dengan hiperinsulinemia dan gangguan toleransi glukosa. ${ }^{18}$ Pada penelitian longitudinal terhadap multietnik dewasa muda yang diamati hingga 6 tahun, Ferris $\mathrm{dkk}^{9}$ melaporkan bahwa mikroalbuminuria berhubungan erat dengan obesitas berat $(\mathrm{BMI} \geq 35)$.

\section{Dislipidemia}

Anak dengan obesitas mempunyai profil lemak dan lipoprotein yang berbeda dengan anak normal, sehingga anak dengan obesitas merupakan risiko tinggi terhadap penyakit kardiovaskular dibandingkan dengan yang tidak obes, terutama pada masa pubertas. Glowinska dkk ${ }^{29}$ melaporkan bahwa anak dengan obesitas mempunyai kadar kolesterol LDL dan trigliserida yang lebih tinggi serta kadar kolesterol HDL yang lebih rendah dibandingkan dengan anak seusianya yang tidak obes. Friedland $\mathrm{dkk}^{30}$ melaporkan 52\% anak obes berumur 8-12 tahun mempunyai kadar kolesterol total yang meningkat, sedangkan pada anak tidak obes hanya sebesar $16 \%$. Kadar lipoprotein yang tinggi pada anak masa pertumbuhan perlu mendapat perhatian karena cenderung akan berlanjut pada masa dewasa. Sekitar 50\% anak dan remaja dengan kolesterol total atau kolesterol LDL di atas persentil ke-75 akan tetap dengan kadar yang tinggi pada masa dewasa. Dislipidemia berperan terhadap terjadinya progresivitas aterosklerosis dan penyakit ginjal.

\section{Sindrom metabolik}

Sindrom metabolik pada anak dikategorikan jika memenuhi 3 dari 5 kriteria berikut yaitu 1 . obesitas sentral, 2 peningkatan kadar trigliserida, 3 penurunan kadar kolesterol high density lipoprotein (HDL), 4. kadar gula darah puasa meningkat, dan 5 hipertensi. ${ }^{31}$ Sindrom metabolik sebagai akibat obesitas juga merupakan faktor risiko independen terhadap PGK dan PGSA. Hal ini semakin menambah keyakinan tentang hipotesis bahwa pada sindrom metabolik, penurunan sensitivitas insulin atau hiperinsulinisme merupakan faktor yang sangat penting dalam terjadinya kerusakan ginjal (renal injury). ${ }^{3}$ Di samping hiperinsulinemia, komponen sindrom metabolik lainnya juga berperan dalam terjadinya kerusakan ginjal. ${ }^{27}$

\section{Manifestasi klinis dan diagnosis}

Insidens gangguan ginjal terkait obesitas, bentuk sekunder GSFS akibat obesitas, meningkat selama 20 tahun terakhir, bahkan pada anak. 3,9,32

Pada GSFS akibat obesitas, terdapat proteinuria bermakna tanpa edema, kadar albumin serum sedikit rendah dan kolesterol total normal atau sedikit meningkat. Proteinuria dan disfungsi ginjal progresif terjadi akibat respons maladaptif glomerulus terhadap peningkatan jaringan adiposa.

Pada anak obes non-diabetik yang secara klinis sehat dapat ditemukan mikroalbuminuria yang lebih tinggi dibandingkan anak dengan berat badan normal. Hal ini menunjukkan adanya disfungsi glomerulus awal sebagai konsekuensi obesitas pada masa anakanak. Karakteristik klinis dan histologi ini menyerupai deskripsi obesity-related focal segmental glomerulosclerosis yang ditemukan pada dewasa. ${ }^{2}$

Gejala klinis GSFS pada pasien dewasa obes dan non-obes dengan BMI tinggi berbeda dari GSFS primer, yaitu kadar albumin yang cenderung lebih tinggi, sering di atas $3 \mathrm{~g} / \mathrm{dL}$, kadar kolesterol total sedikit meningkat tetapi sering $<300 \mathrm{mg} / \mathrm{dL}$, proteinuria sedang, tekanan darah cenderung normal atau hanya sedikit meningkat dan edema minimal atau bahkan tanpa edema dengan progresivitas penyakit yang lebih lambat. ${ }^{2,13,33}$

Terdapat sedikit laporan mengenai gangguan ginjal terkait obesitas yang menyebabkann PGSA pada anak dan remaja, tetapi pasien obes berusia muda lebih sering bermanifestasi berupa peningkatan laju ekskresi albumin 
urin, mikroalbuminuria, yang berkembang menjadi proteinuria. Anak obes memiliki ukuran ginjal yang lebih besar sebagai akibat peningkatan berat badan yang berhubungan erat dengan ukuran berbagai organ. ${ }^{3}$

Gambaran histologis ginjal pada gangguan ginjal terkait obesitas tampak berupa hipertrofi glomerulus, GSFS, peningkatan matriks dan selularitas mesangium, morfologi foot process yang utuh, dan tidak ada bukti proses inflamasi ataupun proses imun. Gambaran histologi proteinuria terkait obesitas pada dewasa dapat berupa perubahan sklerotik fokal di hilar, proliferasi dan hipertrofi mesangium, fokus hialinosis dan glomerulomegali, dan fusi foot process sering minimal dan fokal. $2,13,33$

\section{Tata laksana}

Terdapat bukti kuat bahwa penurunan berat badan merupakan tata laksana penting pada gangguan ginjal terkait obesitas. Hal ini pertama kali terlihat pada penelitian dengan hewan coba yang melaporkan penurunan lesi GSFS dengan mengurangi asupan diet dan penurunan berat badan. ${ }^{2}$ Penelitian pada hewan coba yang dilakukan oleh Maddox dkk. melaporkan restriksi diet dapat memperlambat terjadinya proteinuria dan sklerosis glomerulus, terutama jika restriksi diet tersebut dilakukan sejak usia muda. Efek protektif restriksi diet ini dapat disebabkan oleh reversibilitas hiperperfusi glomerulus dan hipertensi kapiler glomerulus. ${ }^{20}$ Mekanisme penurunan berat badan dalam memperbaiki proteinuria terjadi karena kontrol tekanan darah yang lebih baik, perbaikan profil lipid serum, kontrol glikemik yang lebih baik, penurunan kadar leptin dalam sirkulasi darah, reversibilitas hiperfiltrasi glomerulus, dan penurunan aktivasi sistem renin-angiotensin-aldosteron. ${ }^{15}$

Terapi lainnya adalah penggunaan obat yang memiliki efek negatif terhadap sistem renin-angiotensin, seperti angiotensin converting enzyme (ACE) inhibitors atau angiotensin receptor blockers. Pada hewan coba, penggunaan $A C E$ inhibitor terbukti dapat menormalkan proteinuria, kadar kolesterol, lesi glomerulus dan morfologi podosit. Pada anak dengan obesity-related focal segmental glomerulosclerosis, pemberian $A C E$ inhibitor menyebabkan penurunan proteinuria yang bermakna. ${ }^{2}$

Obat yang meningkatkan sensitivitas insulin, seperti peroxisome proliferator-activated receptors- $\alpha$ (PPAR- $\alpha$ ), peroxisome proliferator-activated receptors $-\gamma$
(PPAR- $\gamma$ ) agonis, dan inhibitor hydroxymethylglutarylCoA (HMG-CoA) reduktase dapat diberikan sebagai terapi tambahan untuk mencegah progresivitas penyakit ginjal. Namun kurangnya uji klinis acak terkontrol berskala besar menyebabkan belum ada rekomendasi tentang pemberian obat ini. ${ }^{5}$

Statin terindikasi pada keadaan hiperkolesterolemia. Obat golongan statin berperan melindungi ginjal, tetapi peranannya masih dalam penelitian. Terdapat bukti yang menyebutkan bahwa statin memiliki efek anti-inflamasi, sehingga perlu dilakukan uji klinis lebih lanjut mengenai penggunaan statin pada pasien sindrom metabolik dengan kadar kolesterol normal. ${ }^{13}$

Penurunan berat badan, tata laksana agresif terhadap prediabetes, diabetes dan hipertensi masih merupakan intervensi paling efektif untuk pencegahan PGK. ${ }^{5,25,26}$ Albuminuria merupakan petanda dini PGK sehingga merupakan target pencegahan primer. Beberapa penelitian melaporkan adanya hubungan antara obesitas dengan albuminuria. National Kidney Foundation's Kidney Disease Outcomes Quality Initiative (KDOQI) merekomendasikan skrining albuminuria untuk orang yang berisiko mengalami penyakit ginjal, seperti diabetes, hipertensi, penyakit sistemik lain, dan terdapat riwayat penyakit ginjal dalam keluarga. Obesitas dipikirkan dapat menjadi kriteria skrining baru. ${ }^{9}$

\section{Kesimpulan}

Obesitas merupakan keadaan disekuilibrium berbagai mekanisme homeostasis tubuh, termasuk di antaranya sistem ginjal. Obesitas menyebabkan nefromegali dan glomerulomegali, hiperperfusi/hiperfiltrasi serta perubahan intraglomerular. ${ }^{13,15}$ Obesitas merupakan faktor risiko kuat perkembangan dan progresivitas penyakit ginjal. Tantangan penting bagi klinisi adalah mencegah gangguan ginjal terkait obesitas sebelum terjadi kerusakan ginjal yang ireversibel. Usaha mencegah atau menangani obesitas sejak dini memberikan dampak besar terhadap insiden, progresivitas, biaya, dan komorbiditas penyakit ginjal. ${ }^{3}$

\section{Daftar pustaka}

1. Gahagan S. Overweight and obesity. Dalam: Kliegman RM, Stanton BF, St Geme III JW, Schor NF, Behrman RE, penyunting. Nelson Textbook of Pediatrics. Edisi ke-20. 
Philadelphia: Elsevier; 2016.h.307-16..

2. Graf L, Rendy K, Kaskel FJ. Nutrition management in childhood kidney disease: An integrative and lifeciurse approach. Dalam: Avner ED, Harmon WE, Niaedet P, Yoshikawa N, Emma F, Goldstein SL, penyunting. Pediatric Nephrology. Edisi ke-7, Berlin Heidelberg: SpringerReference;2016.h.341-60.

3. Savino A, Pelliccia P, Chiarelli F, Mohn A. Obesity-related renal injury in childhood. Horm Res Paediatr 2010;73:303-11.

4. Badan Penelitian dan Pengembangan Kesehatan Departemen Kesehatan RI. Laporan hasil riset kesehatan dasar (Riskesdas) nasional 2013. Jakarta.

5. Wahba IM, Mak RH. Obesity and obesity-initiated metabolic syndrome : mechanistic links to chronic kidney disease. Clin J Am Soc Nephrol 2007;2:550-62.

6. Wang Y, Chen X, Klag MJ, Caballero B. Epidemic of childhood obesity : implications for kidney disease. Adv Chronic Kidney Dis 2006;13:336-51.

7. USRDS. The United States Renal Data System. Am J Kidney Dis. 2003; 42:1-230.

8. Agnani S, Vachharajani VT, Gupta R, Atray NK, Vachharajani TJ. Does treating obesity stabilize chronic kidney disease? BMC Nephrology 2005;6.

9. Ferris M, Hogan SL, Chin H, Shoham DA, Gipson DS, Gibson K dkk. Obesity, albuminuria, and urinalysis findings in US young adults from the Add Health Wave III Study. Clin J Am Soc Nephrol 2007;2:1207-14.

10. Abrass CK. Overview : obesity : what does it have to do with kidney disease? J Am Soc Nephrol 2004; 15:2768-72.

11. Weisinger JR, Kempson RL, Elridge L, Swenson RS. The nephrotic syndrome : a complication of massive obesity. Ann Intern Med 1974;81:440-7

12. Cohen AH. Massive obesity and the kidney. A morphologic and statistical study. Am J Pathol 1975;81:117-30.

13. Bagby SP. Obesity-initiated metabolic syndrome and the kidney : a recipe for chronic kidney disease? J Am Soc Nephrol 2004;15:2775-91.

14. Papafragkaki D, Tollis G. Obesity and renal disease : a possible role of leptin. Hormones 2005;4:90-5.

15. Praga M, Morales E. Obesity, proteinuria and progression of renal failure. Curr Opin Nephrol Hypertensi 2006;15:481-6.

16. Sowers JR. Metabolic risk factors and renal disease. Kidney Int 2007;71:719-20.

17. Chagnac A, Weinstein T, Korzets A, Ramadan F, Hirsch J, Gafter U. Glomerular hemodynamics in severe obesity. Am J Physiol Renal Physiol 2000;278:817-22.

18. Csernus K, Lanyi E, Erhardt E, Molnar D. Effect of childhood obesity and obesity-related caediovascular risk factors on glomerular and tubular protein excretion. Eur J Pediatr
2005;164:44-9.

19. Jiang T, Wang Z, Proctor G, Moskowitz S, Liebman SE, Rogers T, dkk. Diet-induced obesity in C57BL/6J mice causes increased renal lipid accumulation and glomerulosclerosis via a sterol regulatory element-binding protein-1c-dependent pathway. J Biol Chem 2005;280:32317-25

20. Maddox DA, Alavi FK, Santella RN, Zawada ET. Prevention of obesity-linked renal disease : age-dependent effects of dietary food restriction. Kidney Int 2002;62:208-19.

21. Wong CS, Gipson DS, Gillen DL, Emerson S, Koepsell T, Sherrard DJ, dkk. Anthropometric measures and risk of death in children with end stage renal disease. Am J Kidney Dis 2000;36:811-9.

22. Rosner B, Prineas R, Daniels SR, Loggie J. Blood pressure differences between blacks and white in relation to body size among US children and adolescents. Am J Epidemiol 2000;151:1007-19.

23. Salvadori M, Sontrop JM, Garg AX, Truong J, Suri RS, Mahmud FH, dkk. Elevated blood pressure in relation to overweight and obesity among children in a rural Canadian community. Pediatrics 2008;122:821-7.

24. Sorof I, Daniel S. Obesity hypertension in children: a problem of epidemic proportions. Hypertension 2002;40:441-7.

25. Bijke CECC. Obesity and hypertension in children and adolescents: developing new tools for the diagnosis of two global pediatric challenge. J Med Sci 2013;13:151-9.

26. Flynn JT, Falkner BE. Obesity hypertension in adolescent : epidemiology, evaluation, and management. J Clin Hyoertens 2011;13:323-31.

27. Dornfeld LP, Maxwell MH, Wals A, Tuck M. Mechanisms of hypertension in obesity. Kidney Int 1987;22:254-8.

28. Burgert TS, Dziura J, Yeckel C, Taksali SE, Weiss R, Tamborlane W, dkk. Microalbuminuria in pediatric obesity: prevalence and relation to other cardiovascular risk factors. Int J Obes 2006;30:273-80.

29. Glowinska B, Urban M, Koput A, Galar M. New atherosclerosis risk factors in obese, hypertensive and diabetic children and adolescents. Atherosclerosis 2003;167:275-86.

30. Friedland O, Nemet D, Gorodnitsky N, Wolach B, Eliakim A. Obesity and lipd profiles in children and adolescents. J Pediatr Endocrinol Metab 2002;15:1011-6.

31. Sun SS, Grave DG, Siervogel MR, Pickoff AA, Arslanian SS, Daniels SR. Systolic blood pressure in childhood predicts hypertension and metabolic syndrome later in life. Pediatrics 2007;119:237-46.

32. Hall JE. The kidney, hypertension and obesity. Hypertension. 2003;41:625-33.

33. Griffin KA, Kramer H, Bidani AK. Adverse renal consequences of obesity. Am J Physiol Renal Physiol 2008;294:F685-96. 
Sudung O. Pardede dkk: Gangguan ginjal terkait obesitas

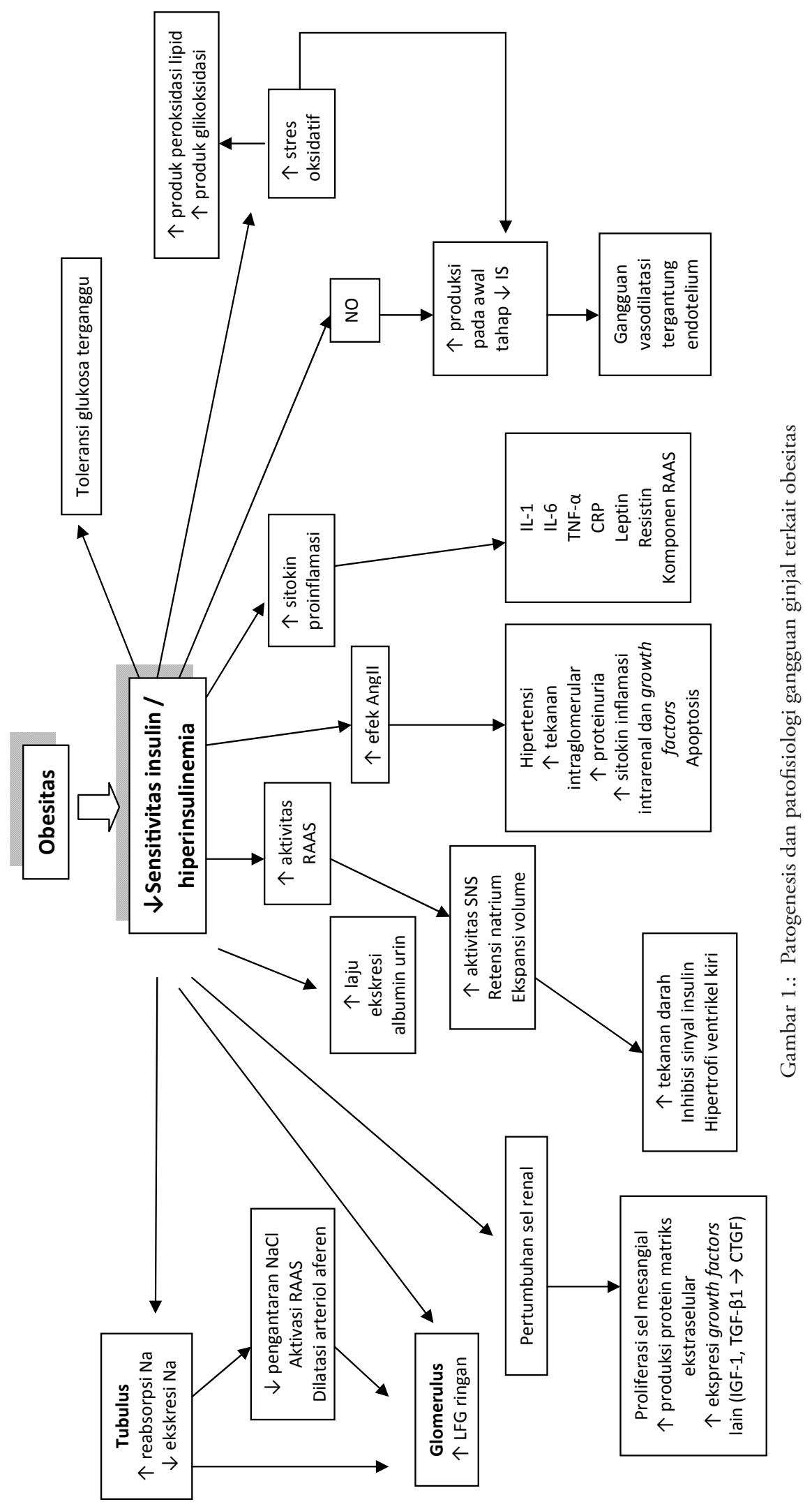

